\title{
ADDIN
}

https://journal.iainkudus.ac.id/index.php/Addin

ISSN: 0854-0594; E-ISSN: 2476-9479

Volume 14, Number 2, August 2020: 275-304

DOI: $10.21043 /$ addin.v14i2.8322

\section{Sufism Based Character Education: Strenghtening the National Character to Traditional Muslim Community in Madura}

\author{
Siswanto \\ Institut Agama Islam Negeri (IAIN) Madura, Indonesia \\ siswanto.abinaufal@gmail.com
}

\section{Abstract}

This article describes model of strengthening the national character values with the Sufism approach in the traditional Madurese Muslim community who has a sectarian and static mindset through the Majlis Maulid wa al-Ta'lim Riyadlul Jannah Madura activities. The strengthening of the national character is based on Islamic teachings which normatively emphasize the ritual and social dimensions. This Majlis builds religious values, love for the country, the spirit of nationality, tolerance, and social care. The pattern of strengthening with the Sufism approach is carried out through the reading of Maulid Simth ad-Durar, shalawat, and qashidah with national character values, mauizhah hasanah, and riyadlah through safari maulid in 40 nights and qiyam al-lail on the last 15 nights of Ramadan. The strengthening of the national character runs optimally influenced by the power of prayer, humility (tawadlu') of the Majlis leaders, hospitality, and noble morals in every Majlis activities.

Keywords: Sufism, Character Education, National Character, Traditional Muslim.

\section{Abstrak}

PENDIDIKAN KARAKTER BERBASIS TASAWUF: PENGUATAN KARAKTER KEBANGSAAN BAGI MASYARAKAT MUSLIM TRADISIONAL DI MADURA. Artikel ini akan menjelaskan tentang 
penguatan nilai karakter kebangsaan dengan pendekatan tasawuf pada masyarakat Muslim tradisional di Madura yang memiliki pola pikir sektarian dan statis melalui aktivitas Majlis Maulid wa alTa'lim Riyadlul Jannah. Penguatan karakter kebangsaan dilandasi oleh ajaran Islam yang secara normatif menekankan pada dimensi ritual dan dimensi sosial. Majlis ini membangun nilai religius, cinta tanah air, semangat kebangsaan, toleransi dan peduli sosial. Pola penguatan dengan pendekatan tasawuf dilakukan melalui pembacaan Maulid Simth ad-Durar, shalawat, dan qashidah bernilai karakter bangsa, penyajian materi mauizhah hasanah, dan riyadlah safari maulid 40 malam serta qiyam al-lail pada 15 malam terakhir bulan Ramadan. Penguatan karakter berjalan optimal dipengaruhi oleh kekuatan doa, kerendahan hati (tawadlu') pimpinan Majlis, serta keistiqamahan dan akhlak mulia pada setiap kegiatan Majlis.

Kata kunci: Tasawuf, Pendidikan Karakter, Karakter Kebangsaan, Muslim Tradisional.

\section{A. Introduction}

The development of technology and global culture tends free from moral and ethic that have been held by the community. Unwittingly, technology has formed human behavior like machines that are based on stimulus (S) and response (R) as in the Behaviorism psychology. The influence of "another world" can defeat and get rid of the own national character. ${ }^{1}$ By global culture, human will lean themselves on humanistic values and feel that they are able to do without help of the transcendental substances. A number of values that have great values and are held in high esteem was begun be ignored, such as respecting leaders, scholars, educators and parents. ${ }^{2}$

Various phenomena of amoral and criminality cases occured in the community must be addressed. ${ }^{3}$ Likewise, cultural diversity

\footnotetext{
${ }^{1}$ Moh. Roqib, "Pendidikan Anak Kreatif Perspektif Profetik," Tadris: Jurnal Pendidikan Islam 9, no. 1 (2014): 27.

${ }^{2}$ Siswanto, "Membudayakan Nilai-nilai Agama dalam Komunitas Sekolah," Karsa: Journal of Social and Islamic Culture 22, no. 1 (2014): 68.

${ }^{3}$ Nashuddin, "Islamic Values and Sasak Local Wisdoms: the Pattern of Educational Character at N.W. Selaparang Pesantren, Lombok," Ulumuna: Journal of Islamic Studies 24, no. 1 (2020): 155-56, DOI: 10.20414/ujis.v24i1.392.
} 
in this country has great potential to cause divisions and conflicts. ${ }^{4}$ If it is left, this nation will be possibility on the verge of collapse. Indonesia is a multiple communities with differencies character countries. $^{5}$ In addition, there are anti-nationalism movements in this country conducted by groups who wanted to disrupt the advantage. ${ }^{6}$ Efforts to create harmony and mutual respect among community groups need to be more empowered and intensively propagated through education and socialization of the four pillars of the nation's state of Indonesia, namely: Pancasila, Undangundang Dasar 1945, Negara Kesatuan Republik Indonesia (NKRI), and Bhinneka Tunggal Ika. ${ }^{7}$

The best step to improve these conditions is instilling character education in all education stages, both formal, non-formal and informal one. Character education is carried out intentionally to develop good character based on core virtues which objectively have good values for individuals and society. Hasan said that the character built is a virtue that applies in society. These virtues contain a number of values, morals, and norms that come from religion, such as honesty, courage to act, trust, and respect for others. ${ }^{8}$

Character education material illustrates the real needs to support people life with others. Many values such as citizenship, cooperation, tolerance, respect the environment, loyalty, help and generosity are behavior components that support a harmonious life with others. The global community need individual awareness

${ }^{4}$ Eka, "Revisiting Character Education from Islamic Perspective: a Quest for Character-Based Education in Indonesia," Ulumuna: Journal of Islamic Studies 21, no. 1 (2017): 2, DOI: 10.20414/ujis.v21i1.1156; Muhammad Miftah, "Multicultural Education in the Diversity of National Cultures," QIJIS: Qudus International Journal of Islamic Studies 4, no. 2 (2016): 168, DOI: 10.21043/qijis.v4i2.1766.

${ }^{5}$ Masrukhin and Supa'at, "The Islamic Mass Organization Contribution in Protecting the Religiosity Inclusive and Diversity in Indonesia," Addin 12, no. 2 (2018): 410, DOI: 10.21043/addin.v12i2.4541.

${ }^{6}$ Badrun, "Islam Nusantara as Strategy for Indonesian Nasionalism Inauguration," Addin 13, no. 2 (2019): 266, DOI: 10.21043/addin.v13i2.6990.

${ }^{7} \mathrm{Abd}$. A'la, et al., "Islamism in Madura from Religious Symbolism to Authoritarianism," Journal of Indonesian Islam 12, no. 2 (2018): 188, DOI: 10.15642/JIIS.2018.12.2.159-194.

${ }^{8}$ Said Hamid Hasan, Pengembangan Pendidikan Budaya dan Karakter Bangsa (Jakarta: Kementerian Pendidikan Nasional, 2010), 3. 
about the diversity of cultures, ethnicities, and religions that try to live together without suspicion and hatred. The global community foster an atmosphere based on values of respect for others, tolerance, cooperation, and positive competition to achieve mutual happiness. ${ }^{9}$

Character education is a cultural internalization process to make person and community ethical and civilized. To strengthen the character education, it is necessary to instill the Sufism values as one of the tools to awaken sleeping souls. Sufism can revive various aspects of human spiritual life that have been neglected and forgotten. In Sufism, there are living traditions and rich in metaphysical, cosmological and psychological doctrines and religious psycho-therapies.

Sufism is a mental attitude that always maintain self purity, worship, simple life, willing to sacrifice for good and to be wise. Sufism efforts to train the soul with various activities that can free itself from the influence of worldly life, so that good behavior is reflected, noble and close to Allah swt. ${ }^{10}$ Character building based on the Sufism values provides a strong foundation and becomes a strong fortress in building the civilization and national character based on Islamic teachings. ${ }^{11}$

The portrait of the majority of traditional Muslim community in Madura indeed seem to reflect the population existence live by Islamic values. This existence in the Madurese cultural aspect confirms that the dynamics of their lives cannot be kept away from Islamic culture and traditions. The Islamic foundation strength in the Madurese community is a characteristic of the cultural structures and traditions that have been passed down for generations. ${ }^{12}$

${ }^{9}$ Imam Sutomo, "Modification of Character Education into Akhlaq Education for the Global Community Life," IJIMS: Indonesian Journal of Islam and Muslim Societies 4, no. 2 (2014): 308, DOI: 10.18326/ijims.v4i2.291-316.

${ }^{10}$ Abuddin Nata, Akhlak Tasawuf dan Karakter Mulia (Jakarta: Raja Grafindo Persada, 2013), 155-156.

${ }^{11}$ Soedijarto, Landasan dan Arah Pendidikan Nasional Kita (Jakarta: Kompas Media Nusantara, 2008), 23.

${ }^{12}$ Mas'udi, "Kesetaraan Suami dan Istri dalam Keluarga: Analisis Kesetaraan Pembagian Kerja dalam Keluarga Madura," Konseling Religi: Jurnal Bimbingan Konseling 
In the context of contemporary religious life, it seems that the interest of traditional muslim communities in Madura towards the Sufism world is increasing. They no longer only need many things related to the mundane, but they also related to hereafter. This can be seen in the many traditional community who attend and participate in the Majlis Maulid wa al-Ta'lim Riyadlul Jannah Madura activities. They always attend to this Majlis to read shalawat to Prophet Muhammad saw. Their enthusiasm shows how important this Majlis is for their religious sense to find peace of mind.

Aryani's research result show that by following the majlis shalawat, congregants feel happiness and optimism in looking at life. They behave more extroverted, do theology more freely, and feel a supportive situation for their religious development. Their motivations in following the majlis shalawat are to get a religious way out, strengthen friendship and Islamic brotherhood, seek knowledge (thalab al-'ilm), and to achieve religious transformation. ${ }^{13}$ Zamhari noted that the recitation of shalawat also has a significant role in Sufi practices. It is believed that the blessing phrase of shalawat can be used as a means for Muslims to attain wusul or ma'rifatullah (the knowledge of God) and to obtain spiritual experiences. ${ }^{14}$

Aini also examines the tradition of Shalawat Diba' Majlis bil Musthafa Yogyakarta. For congregation of Majlis bil Musthafa, this shalawatan tradition is an expression of gratitude for the blessings of Allah swt. The expression of gratitude is manifested by praying to the Prophet and the Prophet is a bridge between humans and Allah swt., which is known as intercession of the Prophet. Intercession of the Prophet occurs in the world and the hereafter. Intercession in the world is faith and Islam for every believer and Muslim. ${ }^{15}$

Islam 7, no. 2 (2016): 23-24, DOI: 10.21043/kr.v7i2.2127.

${ }^{13}$ Sekar Ayu Aryani, "Healthy-Minded Religious Phenomenon in Shalawatan: a Study on the Three Majelis Shalawat in Java," Indonesian Journal of Islam and Muslim Societies 7, no. 1 (2017): 1-30, DOI: 10.18326/ijims.v7i1.1-30.

${ }^{14}$ Arif Zamhari, Rituals of Islamic Spirituality: a Study of Majlis Dhikr Groups in East Java (Canberra: The Australian National University Press, 2010), 53.

${ }^{15}$ Adrika Fithrotul Aini, "Living Hadis dalam Tradisi Malam Kamis Majelis Shalawat Diba' bil Musthafa," Ar-Raniry: International Journal of Islamic Studies 2, no. 1 (2014): 221- 
The research is focused on the study of the philosophical basis for internalizing sufistic values in national character education, internalizing process the national character values, Sufism approach in strengthening national character, and some effort to optimize the strengthening of national character values in in traditional Muslim community in Majlis Maulid wa al-Ta'lim Riyadlul Jannah Madura. This research is categorized as qualitative with phenomenological type. The research data were obtained through interviews, observation, and documentation.

\section{B. Discussion}

\section{The Philosophical Basis in Streghtening the National Character Values}

The streghtening of national character values in traditional muslim community in Madura carried out by Majlis Maulid wa al-Ta'lim Riyadlul Jannah Madura, philosophically, is based on a thought that normatively, Islam teaches about individual and social worship. Relation with Allah swt. (habl min Allah) emphasizes each individual Muslim to become a devout religion follower through direct worship to Him. The manifestation of this individual dimension is the awareness of each congregation in carrying out the worship obligation as 'Abd Allah in manifestating his faith embedded in him.

Faith encourages human to carry out their duties as caliphs on the earth. ${ }^{16}$ Faith is also become a sign for human in searching for various social phenomena. In the social context, human must be able to interpret every social interaction and symbolic meaning occured in the society. If social interaction occurs more dynamic, the meaning that must be had more complex. ${ }^{17}$

35, DOI: $10.20859 /$ jar.v2i1.35.

${ }^{16}$ Munir, "Ajaran Tarekat Alawiyah Palembang dan Urgensinya dalam Konteks Kehidupan Kontemporer," Teosofi: Jurnal Tasawuf dan Pemikiran Islam 8, no. 1 (2018): 12, DOI: 10.15642/teosofi.2018.8.1.1-30.

${ }^{17}$ Amie Primami, Pendidikan Holistik: Format Baru Pendidikan Islam Membentuk Karakter Paripurna (Jakarta: Al-Mawardi Prima, 2013), 170-71. 
From the social side, congregants are required to have good relations with others (habl min an-nas). The concept of the ummah wahidah emphasizes the importance of instilling a national character. The Majlis considers it is important to instill this national character, because of a diminished sense of caring, help each others, and adolescent morality decline in the midst of global development. In order to strengthen nationality sense, it is necessary to inculcate a strong character through the cultivation of aqidah and Sufism values.

The manifestation of the social dimension is the establishment of social life atmosphere among Muslims, especially Majlis congregants who are in harmony and respect each other by maintaining mutual moral and strengthening ukhuwah Islamiyah, wathaniyah, and insaniyah. This dimension became a main point in instilling the national character for the traditional Muslim community in Madura through this Majlis. The concept of strengthening national character values is adjusted to the real condition of the diversity of this nation and adapted to local wisdom in Madurese society.

The existence of this Majlis which was attended by more than 3.000 persons in its routine activities on weekend is expected to become one of the ways in spreading Islam and become a vehicle for the brotherhood among the nation's components. Therefore, one of the missions of this Majlis is to strengthen the ukhuwah Islamiyah (Muslims brotherhood) and embrace all levels in society. This Majlis is open to all groups, does not distinguish social status, background, and others.

The social dimension is closely related to the humanity value, namely the relationship between human and the others (habl min an-nas). Humanity values are expected to form noble moral and can be applied in social life. The social dimension is need to be noticed, because in this era, human values are receding, modern human tend to be more individualistic and materialistic, even hedonistic, forgetting their true identity. Unconsciously, modern human are enslaved by modernity which imprisoned their souls. Collectively, modern human experience soul alienation symptoms 
or split personality. If split personality disease has been suffered by someone, then he no longer has an awareness in relation between his existence with God, at that time, human was in the same state as death. ${ }^{18}$

Strengthening national character in the two dimensions above through Sufism-based character education confirms that Sufism actually has a dual function in holding a role, both as a spiritualreligious movement that carries individual moral messages in order to draw closer to God-even unite with Him-and as a social function in the context of forming social piety to always be sensitive and concerned with social conditions. Of course, by living and practicing the doctrines taught by Sufism. At the same time, it becomes an antithesis to the slanted assumption that Sufism is a source of the Islam decline, because it found some practices of the very exclusive and private sufis. ${ }^{19}$

Even though in fact the Sufism teachings lead to intrinsic awareness with the life meaning humanistly. This essential awareness is in the esoteric realm which always affirms divine values which are the source of all consciousness. Then, the achievement is more to the ultimate happiness, namely in the spirituality dimension. This dimension is the core teachings. Sufism activities have a positive impact on social life that can be an alternative to solve many problems in modern society. ${ }^{20}$

\section{Internalizing the National Character Values}

Strengthening national character values is an important and strategic step in rebuilding the national identity. Majlis Maulid wa al-Ta'lim Riyadlul Jannah Madura instills the national character

\footnotetext{
${ }^{18}$ Nur Holis, "Analisis Sufistik Konsep Suksma Sejati dalam Ajaran Paguyuban Ngesti Tunggal, Pangestu," Ulul Albab 19, no. 2 (2018): 246-47, DOI: 10.18860/ua.v19i2.4974.

${ }^{19}$ Samsun Ni'am, Tasawuf Studies: Pengantar Belajar Tasawuf (Yogyakarta: ar-Ruzz Media, 2014), 216-17.

${ }^{20}$ Irham and Yudril Basith, "Revitalisasi Makna Guru dari Ajaran Tasawuf dalam Kerangka Pembentukan Karakter," Ulul Albab 19, no. 1 (2018): 52, DOI: 10.18860/ ua.v19i1.4901.
} 
values for the traditional Muslim community in Madura through character education based on the Sufism dimension. The national character values instilled to the congregation including.

First, the main value instilled into the congregation is religious character, such as instilling worship values as a obligation in religion, instilling love Allah swt. by increasing zikr, and love the Prophet by reading shalawat. With this religious value, the congregation is expected to be consistent (istiqamah) in carrying out their worship and other religious rituals, solemn and always be hopeful for Allah's pleasure.

To realize this religious value, this Majlis emphasizes the habitual praying at every reading Maulid Simth ad-Durar while expressing gratitude for the gifts bestowed by Allah swt. One of the expressions of gratitude is manifested by strengthening the brotherhood among people, regardless of position, position, race and ethnicity, as well as mutual respect among others. The congregation has the same position in the majlis maulid as the Prophet's people. Khadim Majlis often reminds the congregation that our position in Allah's judgment is the same. There is no difference between one another.

Religious values in the national character are described by obidient attitudes and behaviors in carrying out the religion obligation, being tolerant of other religions practice, and living in harmony with other religion followers. Religious attitudes and behaviors are close to spiritual things. A person is called religious when he feels and tries to get closer to God (as the creator), and is obedient to carrying out his religious teachings. ${ }^{21}$

Second, the national character values internalized is love the homeland and the spirit of nationality. The manifestation of this character value is the congregation has an attitude can strengthen the spirit of national unity and integrity of the Republic of Indonesia. To strengthen the congregation love for the Republic of Indonesia, 
the Simth ad-Durar book by al-Habib Ali bin Muhammad bin Husain al-Habsyi used as a guide for the congregation in reciting shalawat and zikr, including lyrics with the title "NKRI", the national song "17 Agustus 1945", "Garuda Pancasila", "Padang Bulan", and "Ya Lal Wathan". In addition, the congregation accustomed themself to mutual respect, strengthens brotherhood among people, and had social awareness.

Love the motherland is the sense of nationality, sense of belonging, respect, and loyalty that each individual has in the country and reflected in the defending behavior the homeland, protecting it, willing to sacrifice for the sake of the nation and the state, loving customs or culture existed in the country by preserving it. With a sense of homeland love, an individual will try with all efforts to protect, safeguard his sovereignty, honor, and everything he has for his country. ${ }^{22}$

Likewise, the spirit of nationality is described in a way of thinking, acting and having an insight that place the nation and the state interest above themselves and their groups interest. Every citizen certainly has an emotional attachment to the country concerned as a form of pride and belonging to his nation and state. ${ }^{23}$ Thus, the awareness of love the nation-state is an action in the context of practicing the Islamic shari'ah teachings. Shari'ah itself is understood not as a narrow set of rules that refer to one particular school of view, but as an ethical "system of action" based on Al-Qur'an and the Sunnah of the Prophet.

Nationalism is realized in a movement in a multi-nation nation interest. Nation has a totality meaning not differentiate between ethnicity, race, class and religion. Harmonious and equal social relationships are formed on the kinship basis. The all groups interests are institutionalized in various social, political, economic and religious organizations. The individual highest loyalty is for the nation state. This happens cause of common ancestry, language

${ }^{22}$ Kurniawan, 151.

${ }^{23}$ Kurniawan. 
or culture. The most important thing in nationalism is belonging a willingness to unite. ${ }^{24}$

Third, the character value of tolerance instilled in the congregation is in the mutual respect among others, mutual respect for the differences existed among them. The tolerance value is manifested in attitudes and actions that respect differences in ethnicity, opinions, attitudes and the another actions who are different from themselves.

Tolerance as a unifying the nation. In this case, tolerance means respecting and learning from others, appreciating differences, bridging gaps among Muslims so that a common attitude achieved. Tolerance is the beginning of an acceptence attitude that differences are not wrong, instead differences must be respected and understood as wealth.

Substantially, Islam has a high tolerance spirit. This principle must be used as a foundation for Muslims in building a harmonious life system, both among Muslims and non-Muslims. A tolerant attitude can contribute significantly to creat peace in society. ${ }^{25} \mathrm{On}$ the other hand, intolerant attitudes contribute to creat religious and social conflicts. ${ }^{26}$ Qomaruzzaman and Busro stated that Ramadan emphasizes that tolerance is also the basic identity of a Muslim who must participate in justice that is better in the scope of the social life. ${ }^{27}$

Fourth, the social care attitude instilled in the traditional Muslim community in Majlis Maulid wa al-Ta'lim Riyadlul Jannah is to have a deep sense of empathy to help others if they have a disaster. This congregation concern is manifested by helping to

${ }^{24}$ Moh. Abdul Kholiq Hasan, Kamila Adnani, and Moh. Mahbub, "Konstruksi Pemikiran Keagamaan Tentang Nilai-nilai Nasionalisme pada Penceramah di Masjid Agung Surakarta dan Sukoharjo," al-Ulum 18, no. 2 (2018): 486, DOI: 10.30603/au.v18i2.660.

${ }^{25}$ Muhammad Ali, "The Muhammadiyah's 47 th Annual Conference and Islam Berkemajuan," Studia Islamika 22, no. 2 (2015): 383, DOI: 10.15408/sdi.v22i2.1978.

26. M. Khusna Amal, "Counter-Radicalism and Moderate Muslim in Jember," al-Ulum 16, no. 2 (2016): 314, DOI: 10.30603/au.v16i2.152.

${ }^{27}$ Bambang Qomaruzzaman and Busro, "Ricouer's Hermeneutic Reading on Tariq Ramadan's Thought for the Formulation of a Tolerant Islamic Educational Theology," QIJIS: Qudus International Journal of Islamic Studies 7, no. 2 (2019): 206, DOI: 10.21043/qijis. v7i2.5128. 
every natural disaster, by distributing aid to disaster victims like clothes or money obtained through congregation donations, such as in the earthquake in Palu. The congregation concern is also manifested in the social activities such as house renovation, distribution of takjil during Ramadan Month, giving donations to the poors and orphans. All funding for these social activities comes from congregations donation.

Being social and like to help is a universal teaching and is recommended by all religions. Islam also always commands people to like to help others in terms of goodness (Q.S. al-Ma'idah [5]: 2). Every Muslim must have a noble character by showing a good attitude and willing to help others, both fellow Muslims and nonMuslims. Islam makes being kind to others an essential part of a Muslim's faith. ${ }^{28}$

The internalized national character values above are closely related to the horizontal dimension, namely with other humans (habl min an-nas). In the context of Islamic education, these values are categorized as human values expected to establish noble moral and can be applied in social life, including: (a) silaturrahim, namely the love and affection bond among human beings; (b) al-ukhuwwah, namely the brotherhood spirit, especially towards fellow believers (ukhuwwah Islamiyah), which is manifested in an attitude of not insulting each other, degrading other groups, not having prejudice, and so on (Q.S. al-Hujurat [49]: 10-12); (c) al-musawah, namely a viewing that all human beings, regardless of gender, nationality or ethnicity, etc. are the same in vowels and dignity (Q.S. al-Hujurat [49]: 13); (d) al-'adalah, namely a balanced insight or in seeing, assessing, or responding to something or someone. This attitude is also known as middle (wasth). Al-Qur'an states that the believers were designed by Allah swt. to be the middle class (ummatan wasathan) (Q.S. al-Baqarah [2]: 143); (e) at-tawadlu', namely the humility attitude that grows due to human conviction that glory belongs only to God. So it is not right for humans to claim that glory

${ }^{28}$ Marzuki, Pendidikan Karakter Islam (Jakarta: Amzah, 2015), 137-138. 
except with good thoughts and deeds, which only Allah swt. will judge (Q.S. Fathir [35]: 10); (f) insyirah, a generous attitude, namely a willingful attitude to respect others with their opinions and views. An open and tolerant attitude and a willingness to discuss democratically are closely related to this generous attitude; (g) al-munafiqun, has the willingness to help fellow human beings by donating part of his property mandated by Allah swt. to him. ${ }^{29}$

\section{Sufism Approach in Strengthening National Character}

Strengthening the national character values to the traditional Muslim community in Madura requires a value internalization process. Majlis al-Maulid wa al-Ta'lim Riyadlul Jannah Madura applies a certain pattern through the Sufism approach to foster a national character in their souls, so that it will become a habit and culture in their daily life behavior. The pattern of character education in strengthening the national character values for traditional communities in Madura using the Sufism approach is carried out through:

a. Reading shalawat, zikr, and prayer

The pattern of character education based on Sufism in strengthening the values of national character for traditional Muslim communities in Madura is carried out through the reading of Maulid Simth ad-Durar li al-Habib Ali bin Muhammad bin Husain al-Habsyi, Shalawat Syekh Abdul Qadir al-Jailani, and reading zikr Ratib al-Haddad and Ratib al-Aththas. This pattern is conducted by internalizing the character values in the maulid, zikr, and the prayers that they read. In addition, this Majlis also preserves the koloman or tahlilan tradition which is institutionalized in the traditional Muslim community in Madura.

${ }^{29} \mathrm{Abdul}$ Majid and Andayani, Pendidikan Karakter Perspektif Islam (Bandung: Remaja Rosdakarya, 2013), 95-98. 
The common people understand that shalawat is a vehicle for closeness to the Prophet. On the other hand, shalawat is identified with ritual practices accompanied by praises to the Prophet, such as a quite interesting socioreligious phenomenon, namely the culture of praying. ${ }^{30}$

According to Ibn 'Ata' Allah as-Sakandari, zikr is a cleansing oneself process from neglect and forgetfulness, by always attending al-Haqq in their daily lives, repeatedly chanting the name of Allah swt. by heart and orally, or mentioning one of the His characteristics for getting closer to $\mathrm{Him}^{31}$

While the leader of Majlis read zikr, he always prays for our nation, so that it becomes harmonious, peaceful and is always under Allah swt. protection. This sufism-based character education touches the innermost part of the congregation's heart, so that they understand, appreciate and aware to apply the national character values.

Strengthening the nation character is started by building religiosity aspect and strengthening religious rituals for the congregation. Their hearts are instilled with love (mahabbah) for Allah swt. and Rasulullah saw., love the pious people, solemn in praying, living zikr, permeating their own existence as a week servants of Allah swt. ('abd Allah), they have the same position before Allah swt., keep himself away from the pride, jealousy, envy, and other bad behavior.

Loving Allah swt. and His Messenger is the main duty of faith, the most and the largest rules, even it become the basis for every act of faith and religion. Therefore, every practice of faith and religion only comes from a praiseworthy love, and the origin of the praiseworthy love is loving Allah swt., and Allah swt. will only accept a charity that is solely aimed

${ }^{30}$ Qurrata A'yuni, “Shalawat kepada Nabi dalam Perspektif Hadis,” Substantia 18, no. 2 (2016): 166, DOI: 10.22373/substantia.v18i2.3003.

${ }^{31}$ Ibn 'Ata' Allah as-Sakandari, Miftah al-Falah wa al-Mishbah al-Arwah (Mesir: Maktabah al-Mustafa al-Bab al-Halabi, 1381), 4. 
at Him. Prophet Muhammad saw. Said, "Allah swt. said: I am the One who does not need fellowship the most. Whoever does deeds, then associates with me, then I leave him and all his deeds for the one he cursed. The perfection of religion is achieved by the perfection of loving Him." ${ }^{32}$

In this context, the expression of love referred to love for Allah swt. for all the blessings given, loving His Messenger for all his guidances, loving religion for all its guidancet, loving pious people for all their roles and legacy of their traditions. Ali Umar Thayib said, "Man ahabba syay'an aktsar min zikrih (Whoever loves something, he will remember a lot and mention it)." By increasing remembrance and mention of all love for Allah swt., His Messenger, religion, and pious people, it will strengthen faith, strengthen justification or belief into the heart (tashdiq). ${ }^{33}$

\section{b. Riyadlah}

The riyadlah activities carried out in the Majlis are through safari maulid activities of 40 night during Rabi' alAwwal and Rabi 'ats-Tsani month, as well as qiyam al-lail on odd dates during the last 15 nights in Ramadan month. This qiyam al-lail activity is started with visiting maqbarah auliya', masyakhih, and bhuju' which according to the community that they have karamah. The purpose of this visit is to remind a death, as 'ibrah from the righteous people (shalihin) life, pray to the believers souls, and hope for blessings (tabarruk). This is in accordance with the tradition in Java, the practice of tomb visitation is a quite popular tradition known as ziarah, especially to the saints' graves. ${ }^{34}$

${ }^{32}$ Izzuddin Washil and Ahmad Khoirul Fata, "Pemikiran Ibn Taimiyyah Tentang Syari'ah Sebagai Tujuan Tasawuf," Teosofi: Jurnal Tasawuf dan Pemikiran Islam 7, no. 2 (2017): 370-71, DOI: 10.15642/teosofi.2017.7.2.316-338.

${ }^{33} \mathrm{Abu}$ Hamid Muhammad bin Muhammad al-Ghazali, Ihya' 'Ulum ad-Din (Semarang: Toha Putra, 2003), Volume 3, 216.

${ }^{34}$ Mohamad Abdun Nasir, "Revisiting the Javanese Muslim Slametan, Islam, Local Tradition, Honor, and Symbolic Communication," Al-Jami'ah:Journal of Islamic Studies 57, no. 2 (2019): 348, DOI: 10.14421/ajis.2019.572.329-358. 
The rituals recited in this ziarah are tahlil and maulid. After that, it was continued by carrying out ritual activities at the mosque, by doing some prayers, namely Sunnah Hajat, Sunnah Muthlaq, Sunnah Tahajud and continued with reading maulid book Maulid Simth ad-Durar. By this riyadlah, the congregation forge themselves to unite their hearts in loving Allah swt. and the Prophet. Through this riyadlah, the congregation also will pray and ask Allah swt. to grant all their wishes, live in the world in peace and prosperity, and obtain the Allah swt. pleasure in the hereafter.

Riyadlah is a serious effort towards Allah swt., to make closer to Allah swt. Riyadlah is interpreted as spiritual training in doing praiseworthy things either by word, act, or way of attitude towards the right things done according to the level of servant's closeness to his Lord. ${ }^{35}$ The servant's closeness to Lord is classified into three levels, namely common people, khawas (sufi, wali), and khawas al-khawas (prophets and messengers).

Majlis al-Maulid wa al-Ta'lim Riyadlul Jannah members generally are in common people level, so that the model carried out emphasizes more on training themself to behave well by trying to understand the act they do, act sincerely, avoiding riya', and increase to do the truth in daily life, both to God, humans or their environment. ${ }^{36}$

Thus, riyadlah carried out at this level is to educate morals with knowledge, clean charity up by sincerity and increase many things in mu'amalah. Educating morals with knowledge means arranging and cleaning morals according to the knowledge institution, so that a servant does not move, outer or inner except with the knowledge institution, so that all his movements are always weighed with the Islamic balance.

\footnotetext{
${ }^{35}$ Fahruddin, "Tasawuf Sebagai Upaya Membersihkan Hati Guna Mencapai Kedekatan dengan Allah," Ta'lim: Jurnal Pendidikan Agama Islam 14, no. 2 (2016): 69.

${ }^{36}$ Fahruddin, "Tasawuf Sebagai Upaya Membersihkan Hati Guna Mencapai Kedekatan dengan Allah," Ta'lim: Jurnal Pendidikan Agama Islam 14, no. 2 (2016): 70.
} 
c. Mau'izhah hasanah

Mau'izhah hasanah is carried out to emphasize the national character values. In presenting it, the preachers conveyed educational material related to the importance of social and national aspects, such as the importance of avoiding divisions, avoiding the spread of slander (hoax), and encouraging concern for orphans, concern for the poor and others.

Mau'izhah hasanah is one of the preaching approaches in inviting people to virtue in accordance with religious law. In the Al-Qur'an, it is explained that there are three methods of preaching can be used, namely hikmah, mau'izhah hasanah, and mujadalah (Q.S. an-Nahl [16]: 125). Mau'izhah hasanah is an educational method by advising others in a good way, namely many directions to the good in a good language, acceptable and pleased, touching feelings, avoiding rude attitudes, and not scolding or mentioning audience's mistakes, so that the congregation willingly and with their awareness can follow the teachings conveyed by the preacher. ${ }^{37}$

Mau'izhah hasanah conveyed gently and with great affection will raise happiness in mankind. He will guide them on a righteous path, give good and useful lessons, give advice and remind others with kind and gentle language, provide good examples and commendable moral as models to follow and attract interest and desire in Islam..$^{38}$ Educational activities carried out through mau'izhah hasanah must always prioritize the importance of the human side (humanity) in all things. ${ }^{39}$

Thus, mau'izhah hasanah is far from being selfish, emotional agitation and apology. These principles are directed towards the congregation whose intellectual capacity, thought, and spiritual experience belong to common

${ }^{37}$ Samsul Munir Amin, Ilmu Dakwah (Jakarta: Amzah, 2009), 100.

${ }^{38}$ Jum'ah Amin Abdul Aziz, Fiqh Dakwah: Studi atas Berbagai Prinsip dan Kaidah yang Harus Dijadikan Acuan dalam Dakwah Islamiah (Surakarta: Era Intermedia, 2008), 32.

${ }^{39}$ Fathul Bahri an-Nabiry, Meniti Jalan Dakwah: Bekal Perjuangan para Da'i (Jakarta: Amzah, 2008), 242. 
people. In this case, the role of the preacher is as a guide, who nurtures and provides something useful. ${ }^{40}$

The sufism approach in strengthening the national character of the traditional Muslim community in Madura is one of the ways taken by adjusting the conditions and accommodating the local wisdom developed on this island. The da'wah mission chosen by majlis maulid is relevant to the Walisongo mission in the Java Island in spreading Islam. Mukaffa found that Ibrahim Asmarakandi had accommodated local traditions and had a major influence on the Islamization of Java. ${ }^{41}$

\section{Optimizing the Strengthening of National Character Values}

The implementation of character education based on Sufism in strengthening the national character values for the congregation of Majlis Maulid wa al-Ta'lim Riyadlul Jannah Madura will take place optimally because it is influenced by several factors:

a. The power of prayers

The prayer that is said at any time during the reading maulid affects the congregation mindset and act in everyday life. Through this method, their heart purely connected to Allah swt. and His Messenger, eventually in the congregation hearts spiritually will raise a loving Allah swt. and His Messenger. The prayer chanted by the congregation will be connected with the salaf ash-shalih who are usually done through tawassul every time they started Majlis activities. From here will emerge the awareness to behave in accordance with these characters, not because of compulsion.

${ }^{40}$ Siti Uswatun Khasanah, Berdakwah dengan Jalan Debat antara Muslim dan Non Muslim (Yogyakarta: Pustaka Pelajar, 2007), 34.

${ }^{41}$ Zumrotul Mukaffa, "A New Account on the Potrait of Ibrahim Asmarakandi and His Sufism Approach in Islamization of Java," Journal of Indonesian Islam 11, no. 1 (2017): 196, DOI: 10.15642/JIIS.2017.11.1.175-200. 
Prayer is a expression from a servant in asking and praising to Lord. One of worship kind related closely to zikr is prayer, because it is a part of zikr. Even prayer becomes the main or core of worship. Prayer is the most powerful weapon for believers and as an easy worship activity. The awesomeness of the power of prayers chanted by faithful people, Allah swt. will accept all his prayers. Therefore, human are commanded to pray to Him, namely prayers prefected with a humble attitude accompanied by hope and conviction that their prayers can be answered.

In the prayer, actually there are three very important elements, namely: First, a servant's statement about the existence of Allah swt. A servant who is fully convinced that Allah swt. does exist. He is the only Essence who deserves to be asked for help, no one else can benefit and bring harm apart from Himself. So a servant should always pray, ask Allah swt. only with full confidence that Allah swt. with all absolute power will grant all requests. Second, a servant's statement about his helplessness. After making a serious effort, in the end he will surrender to Allah swt. because all the efforts he has made are only a mere effort. He will not be able to determine the final result, but there is still another power, namely Allah swt. His admission that he is a weak being with insufficient knowledge and experience, and no power to determine the result is an essential ingredient in every prayer. Third, the real self-introspection. As Allah swt. servants, we must always be aware of our status before Him. However, behind the weakness, we must also believe in Allah swt. existence, the Almighty Who is able to answer our prayers as long as we are close and obedient in knowing all the prohibitions and obeying all His commands. Conversely, we also must not make mistakes that Allah swt. will definitely not grant our request as long as we still violate all the prohibitions and know all His commands. ${ }^{42}$

${ }^{42}$ Abdul Wahab Rosyidi, "Doa dalam Tradisi Islam Jawa," El-Harakah 14, no. 1 (2012): 91-92, DOI: 10.18860/el.v0i0.2199. 
b. Solemn in reading shalawat, zikr, and prayers

Even though these congregations mostly come from ordinary people and what they read is not in accordance with the text stated in the maulid book, they seem solemn in reading shalawat, some even cry in expressing their petitions to Allah swt. By this solemn will emerge a sense of love (mahabbah) for the Prophet, and in turn will lead to love for the homeland.

Solemn means feeling the Allah swt. attendence, when doing prayers, reciting zikr and pray, so that they feel serenity and peace of mind. Some scholars interpret solemn as a softness of heart, peace of mind, and submission of low will which is caused by lust and a heart that cries when in Allah swt. attendence so that all pride in their heart are lost. In other words, in a solemn condition, a servant only moves according to his Lord order. ${ }^{43}$ Some Arabs use the word solemn to mean ruku'. In addition, solemn to Allah swt. means humbling oneself and feeling contempt before Him. ${ }^{44}$

Solemn has a great and strong influence on one's soul, because khusyu' can lead a person to several behaviors namely: First, cultivating the concentration ability. Second, solemn makes a person humble and tawadlu', because they see Allah's majesty and His splendor. Third, solemn will keep someone in saying and doing useless and making their heart turn from zikr to Allah swt. Fourth, solemn can affect a person's soul when it is in touch with God and becomes devoted to Him, even for a short time. ${ }^{45}$

${ }^{43}$ Lina Kushidayati, "Khusyu' dalam Perspektif Dosen dan Pegawai STAIN Kudus," Esoterik: Jurnal Akhlak dan Tasawuf 2, no. 1 (2016): 47, DOI: 10.21043/esoterik.v2i1.1912.

${ }^{44}$ Muchammad Ichsan, Hanya Shalat Khusyuk yang Dinilai Allah (Yogyakarta: Mocomedia, 2008), 18.

${ }^{45}$ Misa Abdu, Menjernihkan Batin dengan Shalat Khusyu' (Yogyakarta: Mitra Pustaka, 2005), 21-30. 
c. Consistency (istiqamah) in reading maulid and zikr

Majlis activities are carried out routinely and consistently every Sunday night. The choice of this night is to reduce the negative influence caused by the youth Sunday night program. By consistency, the values of national character that are instilled will permeate the congregatioin soul continously. Finally, a desired attitude or character will be formed, which will then manifest in their daily behavior. The consistency shown in this Majlis indicates that it truly instills the love for Allah swt. in worshiping Him and for the Prophet, whose intercession is expected to be interceded on the Judgment Day.

Consistency (istiqamah) is defined in several meaning. It is defined as the someone attitude who has a strong stance or commitment to maintain Islamic values and strive for their consistent enforcement. It is a fundamental obligation and a necessity for the Allah's servants to get husn al-khatimah and His heaven. It can also be interpreted as strenght in facing some various problems in life by cling firmly to Allah's order and the sunnah of the Prophet. ${ }^{46}$

According to Abu al-Qasim al-Qusyairi, in Abd al-Baqi, consistency is only owned by people who truly believe and fear Allah swt. Regarding its virtue, he said, "Whoever has no consistency (istiqamah), then all his efforts will be in vain and all struggles will run aground." ${ }^{47}$ Consistency is an excellent self-management, and it is an implementation of emotional control contained within a person. The key of one's success is influenced by emotional control. Someone who has good emotional control will have a greater percentage of success than even people who have intellectual intelligence.

${ }^{46}$ Jamaluddin Ahmad al-Buny, Menelusuri Taman-taman Mahabbah Shufiyah (Yogyakarta: Mitra Pustaka, 2002), 151.

${ }^{47}$ M. Fuad Abd al-Baqi, Shahih Muslim Syarh an-Nawawi (Beirut: Dar al-Kutub al'Ilmiyah, n.d.), 9. 
Muslims who are consistent (istiqamah) and committed to the Islamic truth values in all life aspects will feel the positive impact throughout his life. The consistent attitude has an impact on the emergence of courage (syaja'ah) in Muslims. He will not be afraid to face all obstacles in life. In addition, consistency will raise calm, peace and happiness, as well as a optimistic (tafa'ul) and avoid being pessimistic in life. He never feel tired and anxious, which eventually emerge to frustration in his life.

d. The simplicity of the Majlis leadership

The Majlis leadership shows a low profile attitude in communicating and associating with congregations. It is an important aspect in cultivating this character. At the same time, this characteristic is a special factor for the congregation to follow the words, suggestions or tausiyah of the head (khadim) in national character behavior. With this personality factor, the congregation feels that it is important to imitate the head's Majlis behavior. The congregation realizes that khadim does not come from a well-known figure, but because of its simplicity, it is able to influence in understanding and applying the national character values.

The attitude of the Majlis' head shows the tawadlu' which is actually a basic and urgent need of every believer. Tawadlu' towards fellow human beings is a noble quality born from the awareness of Allah swt. omnipotence over all of His servants. Humans are weak creatures, needing grace, forgiveness and mercy from Allah swt.

Tawadlu' is often defined as human's awareness of his true position before Allah swt. Therefore, taking the path in that direction means measuring his position before a creature based on this awareness, and considering himself the same as any other human being, or as a citizen of the universe. ${ }^{48}$

${ }^{48}$ Munir, "Ajaran Tarekat Alawiyah Palembang dan Urgensinya dalam Konteks 
A person who has tawadlu' does not looking at himself as higher than others. Tawadlu' is an attitude to humble oneself without underestimating self-esteem, so that other people do not underestimate it. Tawadlu' is humble and behaves gently, where his behavior does not aim to be seen as a praiseworthy person but merely hopes for the pleasure of Allah swt. almighty. ${ }^{49}$

Tawadlu' makes easy for individuals to forgive others who hurt themselves. Tawadlu' people are open to many things. Opened people are open to self-acknowledgment may be contributing to wrongdoing in others that causes others to act unpleasantly. In addition, it is easier for someone to understand the problems occur with humility. If the problem can be understood properly, then forgiveness is easily given to the person who hurt. ${ }^{50}$

e. Cultivating noble character in every Majlis activities

In carrying out some activities, this Majlis prioritizes moral values. The head (khadim) advised the congregation to read the maulid, thus in reciting zikr, prayer is recommended for khudlu', khudlur, and khusyu'. These three mental conditions are very important in the process of instilling a character based on Sufism values.

In essence, Sufism is moral and it come from the heart. ${ }^{51}$ The most important basic principle of Sufism is noble character as promoted by Islam. ${ }^{52}$ The principles of Islamic morality are manifested in life aspects that are characterized by balance, realism, effectiveness, efficiency, principles of

Kehidupan Kontemporer," Teosofi: Jurnal Tasawuf dan Pemikiran Islam 8, no. 1 (2018): 1-30, DOI: 10.15642/teosofi.2018.8.1.1-30.

${ }^{49}$ Yola Tiaranita, Salma Dias Saraswati, and Fuad Nashori, "Religiositas, Kecerdasaan Emosi, dan Tawadhu pada Mahasiswa Pascasarjana," Psikohumaniora: Jurnal Penelitian Psikologi 2, no. 2 (2017): 182, DOI: 10.21580/pjpp.v2i2.1175.

${ }^{50}$ Yola Tiaranita, Salma Dias Saraswati, and Fuad Nashori.

${ }^{51}$ Amin Syukur, Tasawuf Kontekstual: Solusi Problem Manusia Modern (Yogyakarta: Pustaka Pelajar, 2014), 19.

${ }^{52}$ Muhammad Fuaqi Hajjaj, Tasawuf Islam dan Akhlak (Jakarta: Amzah, 2013), 8. 
benefit, discipline, planning, and have a basis for careful analysis. According to Mubarok, in Majid and Andayani, three indicators of a person's moral quality are assessed, namely: First, consistency between what is said and what is done. Second, consistency of orientation, namely the conformity between views in one respect and views in other fields. Third, consistency of simplelife patterns. In sufism, the mental attitude that always maintains self-purity, worship, lives simply, willing to sacrifice for good, and always acts benevolently, in essence, are reflection of noble character. ${ }^{53}$ The influence of Sufism is still ongoing in society in various domains. ${ }^{54}$

Sufism is a manifestation of ihsan. ${ }^{55}$ By ihsan, then sufism contains the meaning of worship sincerily and solemnly, full of submission in a good way. Sufism behaviors include all behavior, both physical and mental, in worship and mu'amalah. Because ihsan or sufism is the soul or spirit of faith and Islam. The combination of faith and Islam in a person will incarnate and animate a person in the good morals. ${ }^{56}$ Sufism as a manifestation of ihsan is an religion appreciation that can offer spiritual liberation which then invites people to know themselves and finally they know God. ${ }^{57}$

\section{Conclusion}

Strengthening the national character of the traditional Muslim community in Madura through Majlis Maulid wa al-Ta'lim Riyadlul Jannah Madura is based on Islamic teachings normatively emphasized the ritual and the social dimension. This strengthening is supported by the missions of Majlis, one of them is to strengthen friendship, ukhuwah Islamiyah and to embrace all levels in society.

\footnotetext{
${ }^{53}$ Majid and Andayani, Pendidikan Karakter Perspektif Islam, 60.

${ }^{54}$ Ridhwan, "Development of Tasawuf in South Sulawesi," QIJIS: Qudus International Journal of Islamic Studies 5, no. 2 (2017): 44, DOI: 10.21043/qijis.v5i2.2412.

${ }^{55}$ Zakiya Fatihatur Rohma, "Sufistic Spirituality: Joint Motive Study in the Tarekat Zawiyah Naqsabandiyah Haqqani Yogyakarta," El-Harakah 22, no. 1 (2020): 62, DOI: 10.18860/el.v22i1.8602.

${ }^{56}$ Syukur, Tasawuf Kontekstual: Solusi Problem Manusia Modern, 87.

${ }^{57}$ Samsul Munir Amin, Ilmu Tasawuf (Jakarta: Amzah, 2015), 11.
} 
National character values internalized through character education based on Sufism include religious values, love for the country, national spirit, tolerance, and social care.

The pattern of strengthening the national character through the sufism approach is carried out through several activities that became Majlis tradition, namely: First, reading maulid to the Prophet, zikr, and prayer as well as reading nasyid or qashidah which contains the national unity value; Second, riyadlah through the 40 night of safari maulid and qiyam al-lail on odd dates for the last 15 nights of Ramadan; Third, deliverying of mau'izhah hasanah material by emphasizing the national character values. Strengthening the national character values takes place optimally, influenced by the power of prayer that is prayed in mujama'ah and devotion, the simplicity and humility (tawadlu') of the Majlis leadership, hospitality, and prioritizing noble moral values in conducting Majlis activities. 


\section{REFERENCES}

Abdu, Misa. Menjernihkan Batin dengan Shalat Khusyu'. Yogyakarta: Mitra Pustaka, 2005.

Aini, Adrika Fithrotul. "Living Hadis dalam Tradisi Malam Kamis Majelis Shalawat Diba' bil Musthafa," Ar-Raniry: International Journal of Islamic Studies 2, no. 1 (2014), DOI: 10.20859/jar. v2i1.35.

A'la, Abd., et al. "Islamism in Madura from Religious Symbolism to Authoritarianism," Journal of Indonesian Islam 12, no. 2 (2018), DOI: 10.15642/JIIS.2018.12.2.159-194.

Ali, Muhammad. "The Muhammadiyah's $47^{\text {th }}$ Annual Conference and Islam Berkemajuan," Studia Islamika 22, no. 2 (2015), DOI: 10.15408/sdi.v22i2.1978.

Amal, M. Khusna. "Counter-Radicalism and Moderate Muslim in Jember," al-Ulum 16, no. 2 (2016), DOI: 10.30603/ au.v16i2.152.

Amin, Samsul Munir. Ilmu Tasawuf. Jakarta: Amzah, 2015. . Ilmu Dakwah. Jakarta: Amzah, 2009.

Aryani, Sekar Ayu. "Healthy-Minded Religious Phenomenon in Shalawatan: a Study on the Three Majelis Shalawat in Java," Indonesian Journal of Islam and Muslim Societies 7, no. 1 (2017):, DOI: 10.18326/ijims.v7i1.1-30.

A'yuni, Qurrata. "Shalawat kepada Nabi dalam Perspektif Hadis," Substantia 18, no. 2 (2016), DOI: 10.22373/substantia. v18i2.3003.

Aziz, Jum'ah Amin Abdul. Fiqh Dakwah: Studi atas Berbagai Prinsip dan Kaidah yang Harus Dijadikan Acuan dalam Dakwah Islamiah. Surakarta: Era Intermedia, 2008.

Badrun. "Islam Nusantara as Strategy for Indonesian Nasionalism Inauguration," Addin 13, no. 2 (2019), DOI: 10.21043/addin. v13i2.6990. 
al-Baqi, M. Fuad Abd. Shahih Muslim Syarh an-Nawawi. Beirut: Dar al-Kutub al-'Ilmiyah, n.d.

al-Buny, Jamaluddin Ahmad. Menelusuri Taman-taman Mahabbah Shufiyah. Yogyakarta: Mitra Pustaka, 2002.

Eka. "Revisiting Character Education from Islamic Perspective: a Quest for Character-Based Education in Indonesia," Ulumuna: Journal of Islamic Studies 21, no. 1 (2017), DOI: 10.20414/ ujis.v21i1.1156.

Fahruddin. "Tasawuf Sebagai Upaya Membersihkan Hati Guna Mencapai Kedekatan dengan Allah," Ta'lim: Jurnal Pendidikan Agama Islam 14, no. 2 (2016).

al-Ghazali, Abu Hamid Muhammad bin Muhammad. Ihya' 'Ulum adDin. Semarang: Toha Putra, 2003.

Hajjaj, Muhammad Fuaqi. Tasawuf Islam dan Akhlak. Jakarta: Amzah, 2013.

Hasan, Moh. Abdul Kholiq, Kamila Adnani, and Moh. Mahbub. "Konstruksi Pemikiran Keagamaan Tentang Nilai-nilai Nasionalisme pada Penceramah di Masjid Agung Surakarta dan Sukoharjo," al-Ulum 18, no. 2 (2018), DOI: 10.30603/ au.v18i2.660.

Hasan, Said Hamid. Pengembangan Pendidikan Budaya dan Karakter Bangsa. Jakarta: Kementerian Pendidikan Nasional, 2010.

Holis, Nur. "Analisis Sufistik Konsep Suksma Sejati dalam Ajaran Paguyuban Ngesti Tunggal, Pangestu," Ulul Albab 19, no. 2 (2018), DOI: 10.18860/ua.v19i2.4974.

Ichsan, Muchammad. Hanya Shalat Khusyuk yang Dinilai Allah. Yogyakarta: Mocomedia, 2008.

Irham and Yudril Basith. "Revitalisasi Makna Guru dari Ajaran Tasawuf dalam Kerangka Pembentukan Karakter," Ulul Albab 19, no. 1 (2018), DOI: 10.18860/ua.v19i1.4901.

Khasanah, Siti Uswatun. Berdakwah dengan Jalan Debat antara Muslim dan Non Muslim. Yogyakarta: Pustaka Pelajar, 2007. 
Kurniawan, Syamsul. Pendidikan Karakter. Yogyakarta: ar-Ruzz Media, 2013.

Kushidayati, Lina. "Khusyu' dalam Perspektif Dosen dan Pegawai STAIN Kudus," Esoterik: Jurnal Akhlak dan Tasawuf 2, no. 1 (2016), DOI: 10.21043/esoterik.v2i1.1912.

Majid, Abdul and Andayani. Pendidikan Karakter Perspektif Islam. Bandung: Remaja Rosdakarya, 2013.

Marzuki. Pendidikan Karakter Islam. Jakarta: Amzah, 2015.

Masrukhinand Supa'at. "The Islamic Mass Organization Contribution in Protecting the Religiosity Inclusive and Diversity in Indonesia," Addin 12, no. 2 (2018), DOI: 10.21043/addin. v12i2.4541.

Mas'udi. "Kesetaraan Suami dan Istri dalam Keluarga: Analisis Kesetaraan Pembagian Kerja dalam Keluarga Madura," Konseling Religi: Jurnal Bimbingan Konseling Islam 7, no. 2 (2016), DOI: 10.21043/kr.v7i2.2127.

Miftah, Muhammad. "Multicultural Education in the Diversity of National Cultures," QIJIS: Qudus International Journal of Islamic Studies 4, no. 2 (2016), DOI: 10.21043/qijis. v4i2.1766.

Mukaffa, Zumrotul. "A New Account on the Potrait of Ibrahim Asmarakandi and His Sufism Approach in Islamization of Java," Journal of Indonesian Islam 11, no. 1 (2017), DOI: 10.15642/JIIS.2017.11.1.175-200.

Munir. "Ajaran Tarekat Alawiyah Palembang dan Urgensinya dalam Konteks Kehidupan Kontemporer," Teosofi: Jurnal Tasawuf dan Pemikiran Islam 8, no. 1 (2018), DOI: 10.15642/ teosofi.2018.8.1.1-30.

an-Nabiry, Fathul Bahri. Meniti Jalan Dakwah: Bekal Perjuangan para Da'i. Jakarta: Amzah, 2008.

Nashuddin. "Islamic Values and Sasak Local Wisdoms: the Pattern of Educational Character at N.W. Selaparang Pesantren, 
Lombok," Ulumuna: Journal of Islamic Studies 24, no. 1 (2020), DOI: 10.20414/ujis.v24i1.392.

Nasir, Mohamad Abdun. "Revisiting the Javanese Muslim Slametan, Islam, Local Tradition, Honor, and Symbolic Communication," Al-Jami'ah: Journal of Islamic Studies 57, no. 2 (2019), DOI: 10.14421/ajis.2019.572.329-358.

Nata, Abuddin. Akhlak Tasawuf dan Karakter Mulia. Jakarta: Raja Grafindo Persada, 2013.

Ni'am, Samsun. Tasawuf Studies: Pengantar Belajar Tasawuf. Yogyakarta: ar-Ruzz Media, 2014.

Primami, Amie. Pendidikan Holistik: Format Baru Pendidikan Islam Membentuk Karakter Paripurna. Jakarta: Al-Mawardi Prima, 2013.

Qomaruzzaman, Bambang and Busro. "Ricouer's Hermeneutic Reading on Tariq Ramadan's Thought for the Formulation of a Tolerant Islamic Educational Theology," QIJIS: Qudus International Journal of Islamic Studies 7, no. 2 (2019), DOI: 10.21043/qijis.v7i2.5128.

Ridhwan. "Development of Tasawuf in South Sulawesi," QIJIS: Qudus International Journal of Islamic Studies 5, no. 2 (2017), DOI: 10.21043/qijis.v5i2.2412.

Rohma, Zakiya Fatihatur. "Sufistic Spirituality: Joint Motive Study in the Tarekat Zawiyah Naqsabandiyah Haqqani Yogyakarta," El-Harakah 22, no. 1 (2020), DOI: 10.18860/el.v22i1.8602.

Roqib, Moh. "Pendidikan Anak Kreatif Perspektif Profetik," Tadris: Jurnal Pendidikan Islam 9, no. 1 (2014).

Rosyidi, Abdul Wahab. “Doa dalam Tradisi Islam Jawa," El-Harakah 14, no. 1 (2012), DOI: 10.18860/el.v0i0.2199.

as-Sakandari, Ibn 'Ata' Allah. Miftah al-Falah wa al-Mishbah alArwah. Mesir: Maktabah al-Mustafa al-Bab al-Halabi, 1381. 
Siswanto. "Membudayakan Nilai-nilai Agama dalam Komunitas Sekolah," Karsa: Journal of Social and Islamic Culture 22, no. 1 (2014).

Soedijarto. Landasan dan Arah Pendidikan Nasional Kita. Jakarta: Kompas Media Nusantara, 2008.

Sutomo, Imam. "Modification of Character Education into Akhlaq Education for the Global Community Life," IJIMS: Indonesian Journal of Islam and Muslim Societies 4, no. 2 (2014), DOI: 10.18326/ijims.v4i2.291-316.

Syukur, Amin. Tasawuf Kontekstual: Solusi Problem Manusia Modern. Yogyakarta: Pustaka Pelajar, 2014.

Tiaranita, Yola, Salma Dias Saraswati, and Fuad Nashori. "Religiositas, Kecerdasaan Emosi, dan Tawadhu pada Mahasiswa Pascasarjana," Psikohumaniora: Jurnal Penelitian Psikologi 2, no. 2 (2017), DOI: 10.21580/pjpp.v2i2.1175.

Washil, Izzuddin and Ahmad Khoirul Fata. "Pemikiran Ibn Taimiyyah Tentang Syari'ah Sebagai Tujuan Tasawuf," Teosofi: Jurnal Tasawuf dan Pemikiran Islam 7, no. 2 (2017), DOI: 10.15642/ teosofi.2017.7.2.316-338.

Zamhari, Arif. Rituals of Islamic Spirituality: a Study of Majlis Dhikr Groups in East Java. Canberra: The Australian National University Press, 2010. 